\title{
new
}

\section{perspectives on turkey}

22 spring 2000 


\title{
NEW PERSPECTIVES ON TURKEY
}

\author{
Coordinating Editors \\ Çağlar Keyder, SUNY-Binghamton \\ Ayşe Öncü, Boğaziçi University \\ Book Review Editors \\ Reşat Kasaba, University of Washington \\ Hakan Yllmaz, Boğaziçi University
}

\section{Editorial Board}

Haldun Gülalp Boğaziçi University, Fuat Keyman Bilkent University, Şevket Pamuk Boğaziçi University, Fikret Şenses Middle East Technical University, Zafer Toprak Boğaziçi University, Insan Tunalı Koç University.

New Perspectives on Turkey is a series of research papers published biannually by the Economic and Social History Foundation of Turkey (Tarih Vakfi), Valikonağı Cad. Samsun Apt. No. 5780220 Nişantaşı, İstanbul.

See back cover for information regarding submissions and other correspondence.

Subscription rates for 4 issues ( 2 years, including air-mail postage): Turkey - US $\$ 28$ (US $\$ 10$ single copies); Europe - US $\$ 60$ (US\$15 single copies); USA and other countries - US\$80 (US\$20 single copies) Correspondence relating to subscriptions, advertising, business matters should be sent to Sales and Marketing Manager, Tarih Vakfi,'Yıldız Sarayı Arabacılar Dairesi, Barbaros Bulvarı, 80700 Beşiktaş, Istanbul (e-mail: pazarlama@tarihvakfi.org.tr).

Internet: www.tarihvakfi.org.tr/npt e-mail: npt@tarihvakfi.org.tr

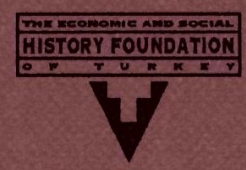

Page Layout: Tarih Vakfi

Printed in Istanbul, July 2000 by Numune Matbaacilik

ISBN 975-333-131-2 


\section{NEW PERSPECTIVES ON TURKEY}

No. 22

Spring 2000

\section{CONTENTS}

\section{ARTICLES}

Athens, Constantinople, "Istambol": Urban Paradigms and

Nineteenth-Century Greek National Identity

K. E. Fleming 1

Gender and National Fantasy: Early Turkish Radio Drama

Meltem Ahiska 25

Kim and Kadinca: Bridging the Gap between

Feminism and Women's Magazines

Süheyla Kirca 61

Cezayir-i Garp: Bringing Algeria back into Ottoman History

Tal Shuval

The Ottoman Empire during World War I

Guest Editor: Nicole A.N.M. van Os

Introduction

Looking beyond the Tribe: Abandoning Paradigms to Write Social History in Yemen during World War I

Isa Blumi

The Prophet Muhammed as an Exemplar in War: Ottoman Views on the Eve of World War I

REVIEW ARTICLE

Greek-Turkish Conflict and Arsonist Firemen 